\title{
Ethnic and migrant penalties in job quality in the UK: the role of residential concentration and occupational clustering
}

Wouter Zwysen and Neli Demireva

\begin{abstract}
Migrants and ethnic minorities in the UK are found to be disadvantaged in their access to work and earnings, but little is known about the characteristics of the jobs they occupy. This paper studies whether migrants and UK-born ethnic minorities attain similar jobs compared to their white British peers by clustering 17 indicators of job quality - covering intrinsic quality, work-life balance, monetary rewards, and employment conditions - into 5 latent classes. We find that non-white migrants are clustered in the worst jobs, while white migrants do relatively well. UK-born ethnic minorities are indeed less likely to work on the best jobs, but the type of disadvantage differs strongly between ethnic groups. Local deprivation drives some of the worse job quality of UK-born minorities while selection into lower-quality occupations and sectors drives much of the disadvantage of migrants. Coethnic support and particularly an economically stronger co-ethnic community in the locality can help shield ethnic minorities from the worst jobs, while ethnic niches in the occupation are associated with low-quality work. Finally, working in migrant-heavy occupations is associated with somewhat lower job quality; primarily affecting other migrants in a possible race to the bottom.
\end{abstract}

Keywords: Job quality; ethnic minorities; migration

Word count: 8996 
Accepted version. Published as: Zwysen \& Demireva (2018). Ethnic and migrant penalties in job quality in the UK: the role of residential concentration and occupational clustering, Journal of Ethnic and Migration Studies.

\section{Introduction}

This paper uses detailed data from the UK to study how the work carried out by UK-born ethnic minorities and migrants differs from that of their white British counterparts. As job quality is a multidimensional concept, analyses focusing on one dimension such as earnings or occupational status could obscure disadvantage in a multitude of work conditions (Muñoz de Bustillo et al., 2011). Thus, we go beyond a singular interpretation of job quality by analysing the combination of job security, work-life balance, intrinsic quality of work, and monetary rewards through latent class analysis. The issue of job quality has been put to the forefront in discussions of how increasing diversity and migration flows to the UK may undercut employment conditions and the quality of work of majority members (Casey, 2016; Corbyn, 2017). By considering both migrants and UK-born ethnic minorities this paper considers whether there is such a separation in the type of work as well as further considering economic assimilation.

Besides introducing a novel way of measuring labour market outcomes, we explore mechanisms leading to disadvantage: a spatial separation of migrants and minorities from the majority - resulting in reduced opportunities and resources through embedded local networks; or a difference in the occupations they work in - which can come about through (self-) selection or clustering networks. The occupational clustering of migrants is particularly relevant if higher competition leads to an undercutting of work conditions among majority members.

\section{Background}

Ethnic diversity ${ }^{1}$ in the UK has increased substantially with the proportion of those selfidentifying as white down from 93\% in the 1991 census to $80 \%$ in the 2011 census, partly driven by

\footnotetext{
${ }^{1}$ Ethnicity is self-reported in most UK data with categories reflecting the migration and colonial past of the UK, including: white British, white other (including Irish), Indian, Pakistani, Bangladeshi, other Asian (sometimes separating Chinese), black Caribbean, black African, other black, other (sometimes separating Arab), mixed ethnicity and other. While these categories are relatively stable people do sometimes 'change' ethnicity as shown in between census rounds (Simpson et al., 2015).
} 
Accepted version. Published as: Zwysen \& Demireva (2018). Ethnic and migrant penalties in job quality in the UK: the role of residential concentration and occupational clustering, Journal of Ethnic and Migration Studies.

rising immigration as net migration to the UK rose from 44,000 to 205,000 over the same period (Jivraj and Simpson, 2015; White, 2017). These changes induced much public discussion on the socioeconomic integration of ethnic minorities and migrants as well as how the changing context affects majority members; but there is little evidence one way or the other (e.g. Casey, 2016; Corbyn, 2017).

Ethnic and migrant labour market disadvantage is consistently found in the UK and well documented. These differences typically persist even when accounting for the advantageous sociodemographic characteristics and qualifications of migrants and ethnic minorities. These remaining gaps are known as 'ethnic penalties' and are the focus of this study. They consist of unobserved differences between migrants and minorities on the one hand and the majority on the other; and structural/institutional constraints as well as ethnic discrimination (Cheung, 2013; Dustmann and Theodoropoulos, 2010; Heath and Cheung, 2006).

This overall finding of strong ethnic penalties hides substantial differences between groups, with other white workers generally doing as well as or even better than white British workers; Chinese and Indian minorities performing somewhat worse; and the largest gaps being found for black Caribbean, black African, Pakistani and Bangladeshi workers. While white migrants are generally found to do well, ethnic minority migrants, particularly those from the New Commonwealth ${ }^{2}$, generally fare poorly. This points to the importance of considering not just migrant status, but also ethnicity among migrants (e.g. Cheung, 2013; Demireva and Kesler, 2011; Dustmann and Theodoropoulos, 2010).

While most studies focus on ethnic penalties in (un-)employment, some also indicate disadvantage in the type and quality of work. When working, minorities are found to be more likely to be overqualified for their job and not given the same supervisory responsibilities or access to further training than similar majority workers (Battu and Sloane, 2004; Lindley, 2009). Economic studies generally find lower earnings compared to similar white British for ethnic minority workers and

\footnotetext{
2 The New Commonwealth refers to former British colonies that decolonised after 1945, often developing nations, in contrast to the Old Commonwealth including USA, Australia, Canada.
} 
Accepted version. Published as: Zwysen \& Demireva (2018). Ethnic and migrant penalties in job quality in the UK: the role of residential concentration and occupational clustering, Journal of Ethnic and Migration Studies.

especially migrants (Blackaby et al., 2005; Dustmann and Theodoropoulos, 2010). Other studies have focused on the status of jobs - often measured as a combination of education and earnings within an occupation - or wider class attainment of migrants and minorities. Li and Heath (2008) show substantial gaps of UK-born and foreign-born ethnic minority men in accessing desirable professional and managerial positions compared to UK-born and migrant white workers with similar qualifications. Cheung (2013) uses data on ethnic minorities to study generational advancement and finds no clear improvement in the UK of accessing professional and managerial occupations - indicating structural constraints faced by minorities. Some part of the difference in type of job is due to a higher proportion of migrants and minorities working as self-employed in the UK than among white British (Cheung, 2013; Li and Heath, 2008). A related literature has focused on the wider social class of minorities finding substantial disadvantage for migrants and to some extent, although improving, for UK-born minorities in reaching higher social class positions, (Li and Heath, 2016).

While this provides some insight into the quality of work these studies generally rely on readily-available single measures like earnings or status. Job quality is a multidimensional concept however and non-monetary aspects - such as autonomy, security and work-life balance - matter strongly when deciding to stay in a job and overall job satisfaction (Clark, 2001; Muñoz de Bustillo et al., 2011). These wider aspects of employment are particularly important in determining overall integration of migrants and ethnic minorities as they reflect important daily work experiences and opportunities for adapting to the mainstream. In doing so this paper contributes to the literature on ethnic penalties by considering the wider variation in job quality - following previous work proposing different typologies of work including both monetary and non-monetary characteristics (e.g. Leschke et al., 2012; Muñoz de Bustillo et al., 2011)³.

\footnotetext{
${ }^{3}$ Existing typologies collect different aspects of work, such as tasks or conditions, and combine these into weighted sums or categorical groups. These schemes are conceptually related to occupational class schemes such as the National Statistics Socio-Economic Classification (NS-SEC) class scheme, which combines occupational status with information on employment contract and establishment size to classify workers. In
} 
Accepted version. Published as: Zwysen \& Demireva (2018). Ethnic and migrant penalties in job quality in the UK: the role of residential concentration and occupational clustering, Journal of Ethnic and Migration Studies.

We consider differences in socio-demographic composition, the local area, and occupational selection to disentangle the mechanisms leading to ethnic penalties in job quality. First, migrants often lack host-country specific skills such as knowledge of the UK labour market, recognized qualifications, or language skills (Duleep and Regets, 1997; Dustmann and Theodoropoulos, 2010). Migrants further face substantial pressure to accept low quality work as they may not be eligible for benefits or their permission to reside may depend on being continuously employed (Anderson, 2010). These pressures play a lesser role in the second generation as they have been raised and educated in the receiving society.

Second, ethnic minorities and migrants live in different localities than the majority - which affects their opportunities as well as the networks formed within the locality which in turn affects the type of work found. While evidence of actual segregation in the UK is sparse (Simpson and Finney, 2010) there can be an important dearth in local resources by which migrants and minorities may be disproportionately affected (Feng et al., 2015). Within these deprived areas there are few opportunities for both minorities and the majority to find good jobs, leading to more precarious work or longer commutes to access good jobs (e.g. Hellerstein et al., 2008).

The local area further affects networks and resources available in job search (Bayer et al., 2008). This can be especially important for migrants whose networks are anchored in their locality (Ryan, 2007). Ethnic minorities as well as migrants rely strongly on local community social networks and informal contacts to find work (Battu et al., 2011; Dustmann et al., 2016), partly as a result of historic patterns of labour recruitment or the conscious avoidance of discriminatory employers (Frijters et al., 2005). Even when local co-ethnic communities increase the probability of finding work (Patacchini and Zenou, 2012), the co-ethnic networks are likely of substantially lower quality and of little use for integrating workers into mainstream jobs compared to networks including the majority.

contrast to wider social class schemes we only focus on the economic aspect, rather than social or cultural capital. 
Accepted version. Published as: Zwysen \& Demireva (2018). Ethnic and migrant penalties in job quality in the UK: the role of residential concentration and occupational clustering, Journal of Ethnic and Migration Studies.

Job search through these informal co-ethnic networks could then lead to lower-quality precarious jobs compared to the use of bridging contacts (Lancee, 2016), as Zuccotti and Platt (2016) demonstrated for Pakistani and Bangladeshis in the UK. Battu and Sloane (2004) also show that non-white workers are more likely to be overqualified when living in a ward with more co-ethnics, while this was the opposite for the white British. The effect of the co-ethnic community on job quality depends on the resources embedded within this community, which will differ between groups (Edin et al., 2003).

Third, ethnic minorities and migrants select into different occupations than the majority which can explain differences in job quality. One reason for this lies in the use of co-ethnic networks to find work in firms and occupations in which many other co-ethnics already work (Dustmann et al., 2016). These jobs are often precarious and low-paid however (Brynin and Guveli, 2012; Semyonov and Herring, 2007). Occupational segregation may further arise from among others discrimination, selective application in reaction to perceived discrimination, or spatial segregation. Elliott and Lindley (2008) and Brynin and Güveli (2012) show that accounting for occupational segregation explains much of ethnic and migrant pay gaps.

Ethnic minorities and migrants may be clustered in occupations that are more vulnerable to increased competition from new migrants as they enter the UK labour market. This increased competition is likely to mainly affect vulnerable workers, such as other migrants and ethnic minorities (Boeri et al., 2015).

In this paper we add to the growing literature on labour market inequality among ethnic minorities and migrants in the UK by considering the actual jobs carried out in more detail. We expect migrants to be over-represented in the lowest-quality jobs compared to both the white UK-born majority and their UK-born co-ethnic counterparts; and further expect non-white minorities particularly Pakistani, Bangladeshi and black minorities - to work on lower quality jobs than white workers, regardless of country of birth. Socio-demographic composition, the area of residence, and the occupation are expected to partly account for these differences. 
Accepted version. Published as: Zwysen \& Demireva (2018). Ethnic and migrant penalties in job quality in the UK: the role of residential concentration and occupational clustering, Journal of Ethnic and Migration Studies.

We further expect ethnic gaps in job quality - for both UK-born and migrant minorities - to be smaller for those living in stronger co-ethnic communities with more resources. At the occupational level we expect ethnic clustering to be associated with lower-quality jobs. Finally, we expect a higher concentration of migrants in the occupation to be associated with worse job quality for everyone, including those of majority members.

\section{Data and methods}

\subsection{Data and sample}

This paper uses Understanding Society (UKHLS) ${ }^{4}$ which is a large-scale household study following respondents over 7 waves between 2009 and 2017 (Knies, 2017). It also holds a large ethnic minority boost sample which oversampled respondents from the most prominent ethnic minority groups in the UK. We restrict the sample to employees with non-missing information on crucial variables aged 1664 , resulting in 68,392 observations. We differentiate between ethnicity and migrant status by grouping respondents into 9 groups: white UK-born workers ${ }^{5}$, white migrants ${ }^{6}$, Indian UK-born ${ }^{7}$, Pakistani UK-born ${ }^{8}$, Bangladeshi UK-born ${ }^{9}$, south-Asian migrants ${ }^{10}$, black Caribbean UK-born ${ }^{11}$, black African UK-born ${ }^{12}$ and black migrants ${ }^{13}$. Descriptive statistics of all variables can be found in table A1 in the supplementary material.

\footnotetext{
${ }^{4}$ University of Essex. Institute for Social and Economic Research, NatCen Social Research, Kantar Public. (2017). Understanding Society: Waves 1-7, 2009-2016 and Harmonised BHPS: Waves 1-18, 1991-2009. [data collection]. 9th Edition. UK Data Service. SN: 6614

${ }^{5}$ Consisting of white British $(\mathrm{N}=55,773)$ and other white $(\mathrm{N}=552)$.

${ }^{6}$ Consisting of white British $(\mathrm{N}=1,390)$ and other white $(\mathrm{N}=2,147)$.

${ }^{7} \mathrm{~N}=1,105$

${ }^{8} \mathrm{~N}=559$

${ }^{9} \mathrm{~N}=327$

${ }^{10}$ Consisting of Indian ( $\left.\mathrm{N}=2,043\right)$, Pakistani ( $\left.\mathrm{N}=655\right)$, and Bangladeshi ( $\left.\mathrm{N}=563\right)$.

${ }^{11} \mathrm{~N}=933$

${ }^{12} \mathrm{~N}=247$

${ }^{13}$ Consisting of black Caribbean ( $\left.\mathrm{N}=584\right)$ and black African $(\mathrm{N}=1,514)$.
} 
Accepted version. Published as: Zwysen \& Demireva (2018). Ethnic and migrant penalties in job quality in the UK: the role of residential concentration and occupational clustering, Journal of Ethnic and Migration Studies.

\subsection{Variables}

Measuring job quality

Several models have been proposed to identify the key aspects of job quality by studying the association of employment aspects with a measure such as quitting or job satisfaction (e.g. Clark, 2001; Jencks et al., 1988). Muñoz de Bustillo and co-authors (2011) identify 5 key aspects of job quality that contribute to wellbeing: pay; intrinsic quality of work, which captures skill use and autonomy as objective measures; employment quality which consists of contractual stability and development opportunities; health and safety; and work-life balance. The comparable European Job Quality Index devised by the European Trade Union Institute comprises wages; non-standard forms of employment; working time and work-life balance; working conditions and job security; skills and career development; and collective interest representation (Leschke et al., 2012).

The Understanding Society dataset allows us to examine these different aspects of job quality through extra modules in waves 2,4 and 6 . We capture monetary rewards through an indicator of whether hourly wages, adjusted for inflation, are in the top or bottom quartile of the sample; whether respondents are paid per hour or salaried; whether the respondent's pay includes bonuses or profit shares, whether they receive annual pay increments, and whether they are offered an employer-run pension scheme. Work-life balance consists of a dummy variable on whether respondents sometimes or mainly work on weekends rather than almost never; an indicator of whether they mainly work standard hours - during the day - or also evenings, at nights or with varying hours and rotating shifts; an indicator of whether respondents can discuss a change in hours easily based on circumstances; as well as a variable indicating their employer offers 2 or more flexibility schemes (working part-time, working term-time only, job sharing, flexi-time, working a compressed week, working annualised hours, working from home on a regular basis, or other flexible working arrangements). Intrinsic quality of work is measured through autonomy at work -being in the lower quartile, middle $50 \%$ or 
Accepted version. Published as: Zwysen \& Demireva (2018). Ethnic and migrant penalties in job quality in the UK: the role of residential concentration and occupational clustering, Journal of Ethnic and Migration Studies.

top $25 \%$ of a scale ${ }^{14}$ combining reported autonomy over whether respondents have a lot, some, a little, or no autonomy over job tasks, work pace, work manner, task order, and work hours -; a dummy variable indicating respondents are somewhat, mostly or completely dissatisfied with their work; as well as a dummy variable indicating respondents are in the top quartile of worry about their job, measured as a scale of how often respondents feel tense, uneasy, worried, depressed, gloomy, or miserable about work ${ }^{15}$. Finally, we capture employment quality by including a dummy on how likely respondents think they are to lose their job in the next 12 months, and whether they work on a temporary contract. We further include an indicator of whether respondents expect any possibility of career advancement by indicating it is very likely to get a better job with the same employer or access to work-related training in the next 12 months.

The responses to employment conditions were carried forward/backward to other waves for respondents who remained in the same job with the same employer. As this information is only available for employees the self-employed are excluded.

\section{Socio-demographic composition}

We include information on whether dependent children are present in the household - which is more likely for all minority groups excepting black Caribbean - as well as age; whether workers cohabit; urbanity; a dummy for whether respondents live in the South-East including London; and qualifications. Qualifications are more polarized among most ethnic minority groups than among UKborn white workers as both the share of lower qualified and the share of graduates are higher.

\section{Local area characteristics}

To capture differences in resources and opportunities at the local level we use information from the 2011 Office for National Statistics (ONS) census at the lower super output area (LSOA) ${ }^{16}$. We include

\footnotetext{
${ }^{14}$ Cronbach's alpha 0.85

${ }^{15}$ Cronbach's alpha 0.85

${ }^{16}$ A LSOA comprises between 1,000 and 3,000 people and is used here to approximate the immediate local network.
} 
Accepted version. Published as: Zwysen \& Demireva (2018). Ethnic and migrant penalties in job quality in the UK: the role of residential concentration and occupational clustering, Journal of Ethnic and Migration Studies.

the overall employment rate as an indicator of employment opportunities and further include the share of people working on professional/managerial jobs and the share of people with tertiary degrees in the local area to capture quality of resources. Diversity is measured by the inverse of the Herfindahl index ${ }^{17}$ where a higher value indicates more ethnic diversity.

Besides the overall deprivation and diversity in the locality we capture the presence of an ethnic network by including the share of co-ethnics in the local area as well as their resources through the share of professional/managerial workers among co-ethnics ${ }^{18}$.

\section{Employment and occupation}

Differences in job quality may come about through differences in the type of firms or occupations for which minorities and migrants work. We include data from Understanding Society on the sector for which minorities work, indicating black Caribbean and black African workers are more likely to work in the public sector than whites, while south-Asian minorities are more likely than whites to work in the private sector. We further include a variable on the size of the firm for which respondents work and the large occupational groups from the standard occupational classification.

Occupational clustering is captured through exposure to migrants, approximating the competition faced by migration, and exposure to co-ethnics, capturing the ethnic niche, in the 3-digit occupation (SOC2000), estimated from the UK Quarterly Labour Force Survey $2009-2017^{19}$ by year of survey and government office region. We follow Aslund \& Skans (2010, p.477) in measuring over-exposure to migrants or ethnic minorities, computed as the ratio of the share of migrants or ethnic minorities over the share that would be expected to randomly occur given the distribution of age, $(16-24 ; 25-49 ; 50-$ 64), education (at most lower secondary; upper secondary or other; post-secondary), cohabiting, and

\footnotetext{
${ }^{17}$ This is 1 minus the sum of the squared shares of each ethnic group within the Isoa, and it could be interpreted as the likelihood that two random people in the locality belong to different groups (Schaeffer, 2014).

${ }^{18}$ At this low local level, ethnicity is only available in large categories: white British; white other; Asian; Black. For the share of co-ethnics more detail is available.

${ }^{19}$ Only the first two quarters of 2017 were used. The LFS is a quarterly representative survey on the UK population covering among others employment status.
} 
Accepted version. Published as: Zwysen \& Demireva (2018). Ethnic and migrant penalties in job quality in the UK: the role of residential concentration and occupational clustering, Journal of Ethnic and Migration Studies.

gender, within an occupation. The log of this exposure indicates whites generally work in occupations with fewer migrants than would be expected, while Bangladeshi and black African workers are more clustered in migrant-dominated occupations. South-Asian and black African respondents generally work in occupations in which their own groups are over-represented which indicates these groups are more likely to work in niche occupations through ethnic networks (Dustmann et al., 2016).

\subsection{Methodology}

Latent class analysis: grouping job quality

All job quality indicators are combined through latent class cluster analysis to capture job quality. The underlying logic of the model is that the observed scores on job quality indicators are dependent upon the unobserved class or type of job someone belongs to and are unrelated within a class (Vermunt and Magidson, 2002).

The model estimates the probability of being in a certain latent class; and item-response probabilities conditional on class membership. These posterior probabilities are used to identify the substantive meaning of the class. We select the appropriate number of classes by considering the substantive meaning of the classes and comparing how well they fit the data by considering the log likelihood and information criteria (Lanza et al., 2015; Vermunt and Magidson, 2002). We then assign everyone their most likely class ${ }^{20}$.

\section{Predicting Class membership}

The next step of the analysis focuses on the determinants of belonging to a certain class by predicting class membership for each individual. We estimate sequential multinomial logistic regression models ${ }^{21}$ on belonging to class " $\mathrm{i}$ " as shown in Equation 1 by adding: (1:SD) socio-demographic control variables including highest obtained qualification, dependent child in the household, cohabiting, age (squared),

\footnotetext{
${ }^{20}$ They are assigned the class for which they have the highest predicted probability to belong, as long as it was over 0.5

${ }^{21}$ We do not estimate a multilevel model as on average only 1.3 respondents live in the same LSOA.
} 
Accepted version. Published as: Zwysen \& Demireva (2018). Ethnic and migrant penalties in job quality in the UK: the role of residential concentration and occupational clustering, Journal of Ethnic and Migration Studies.

living in an urban area, living in the South-East of the UK and year of the survey; (2: Local) the share of graduates, workers in professional and managerial positions and employment rate in the local area as well as diversity; (3: Occ) 1-digit occupational dummies, the log of exposure to migrants, sector of employer and firm size; to a base-line model (0: base) which includes our origin variable combining ethnicity and migrant status. These sequential models indicate the importance of residential and occupational clustering in accounting for minority and migrant disadvantage through a reduction in the estimated coefficients for origin $\left(\beta_{1}\right)$, expressed as the average marginal effect (AME) of the difference in the probability of class membership compared to the majority of UK-born whites.

$\operatorname{Pr}\left(\right.$ Class $\left._{i}\right)=f\left(\alpha+\beta_{1} *\right.$ Origin $+\gamma_{1} * S D+\gamma_{2} *$ Job $+\gamma_{3} *$ Local $+\gamma_{4} *$ Occ $\left.+\varepsilon\right)$

To study whether diversity and resources within the co-ethnic network and competition of migrants affect the job quality of ethnic minorities and migrants more than they do whites we interact the share of co-ethnics in the local area, the employment rate among co-ethnics, the exposure to migrants in the occupation, and the exposure to co-ethnics in the occupation, in separate models with origin status including all other control variables.

All analyses are weighted to account for different selection probabilities and attrition, and separated by gender. To account for repeated observations and allow for the added measurement error due to using an estimated dependent variable we cluster the standard errors by person (Lewis and Linzer, 2005).

\section{Results}

\subsection{Job quality through Latent Class Analysis}

We compared goodness-of-fit of latent class models with up to 7 classes and found that a model with 5 classes satisfactorily explains the observed relations between the 17 binary indicators of job quality. Adding further classes does not change the interpretation of the main classes substantially and improved the model fit less. Test statistics are shown in table 1. 
Accepted version. Published as: Zwysen \& Demireva (2018). Ethnic and migrant penalties in job quality in the UK: the role of residential concentration and occupational clustering, Journal of Ethnic and Migration Studies.

[Table 1 about here]

[Table 2 about here]

Table 2 then presents these five estimated classes: their size, the posterior probabilities of each indicator and a summary of the relative job quality. The largest class comprises $28 \%$ of workers. We name this the class of high-quality jobs as they have very good outcomes on all indicators. They receive high pay, bonuses and coverage of a pension scheme; have flexibility and work primarily during the day-time in the week making for good work-life balance; mainly work on permanent contracts with high job security and prospects of training and/or promotion; have high autonomy, are satisfied with their jobs and experience relatively little stress and worry about work. At the other end of the spectrum is a class of bad jobs containing $21 \%$ of workers. They are mainly paid per hour with very low wages, few bonuses or pay rises and only a minority benefiting from a pension scheme; they work less sociable hours with very little flexibility thereby limiting work-life balance; temporary contracts are more common and workers feel less secure and have low prospects of training or promotion; and have very low intrinsic work quality with low autonomy as well as low job satisfaction. In between these two opposite classes are three more mixed clusters of middling jobs. We name the smallest class (16\%) "high intrinsic / low rewards" as it combines high intrinsic job quality and flexibility with unsociable hours and low monetary rewards. Workers in this class are characterized by low wages and little coverage by pension scheme and bonus/pay rises as well as working unsociable hours. They stand apart from the bad jobs in their much higher flexibility, especially informally; their better employment conditions with more job security and somewhat more prospects of advancements; and especially in their very high intrinsic job quality with high autonomy, high job satisfaction and low worry comparable or even somewhat better to the high-quality jobs. A fourth class (18\%) is characterised by polarized job quality. Workers in this class receive high monetary rewards, with high pay, pay rises and almost universal pension scheme coverage; and enjoy high employment quality with high job security and prospects for training/advancement. These high rewards and employment quality are 
Accepted version. Published as: Zwysen \& Demireva (2018). Ethnic and migrant penalties in job quality in the UK: the role of residential concentration and occupational clustering, Journal of Ethnic and Migration Studies.

offset by unsociable hours and low flexibility; as well as low autonomy, low job satisfaction and high degrees of stress and unease about their job. The final class (17\%) is named "unhappy 9 to 5 " and is characterised by very low intrinsic job quality and employment quality, combined with average monetary rewards - but high frequency of incremental pay rises and pension scheme coverage - and very high work-life balance through standard hours during the week and official flexibility schemes.

These classes are data-driven clusters of job quality indicators which highlight the work conditions often occurring together. While not intended as a social class scheme, it is nonetheless useful to compare these classes with often used indicators of occupational status. Figure 1 shows the distribution of membership among the five latent classes described above within each group of the National Statistics Socio-economic Classification (NS-SEC) which is based on occupational codes. There is some overlap between the two, with the high-quality jobs dominating the high managerial (78\%) and high professional (60\%) occupations; and bad jobs being more prominent among semi-routine $(44 \%)$ and routine (55\%) occupations. However, job quality varies even within the best and worst classes and highlights the large heterogeneity within the more middling status occupational groups (intermediate; supervisor and technical positions; semi-routine). While occupational class groupings are relatively static, there is somewhat more movement from one wave of the survey to the next in the job quality class into which respondents fall, with $22 \%$ of respondents in the sample changing job quality class from one wave to the next compared to $10 \%$ changing NS-SEC classes. In results not shown here we also estimate the 5 latent class model for 2 subsamples including only migrants and only UK-born ethnic minorities, which results in the conceptually same 5 groupings indicating these typologies are not merely driven by the majority.

[Figure 1 about here]

\subsection{Ethnic and migrant differences in job quality}

Figure 2 presents the distribution of job quality by origin and gender. The descriptive patterns suggest that among men UK-born white and black African, and white migrants are most likely to work 
Accepted version. Published as: Zwysen \& Demireva (2018). Ethnic and migrant penalties in job quality in the UK: the role of residential concentration and occupational clustering, Journal of Ethnic and Migration Studies.

on high-quality jobs, while among women it is more likely for UK-born black Caribbean, UK-born black African and UK-born Indian workers. Working on bad jobs is most likely for black migrant, south-Asian migrant, UK-born Pakistani and white migrant men; and for south-Asian migrant, and UK-born Bangladeshi women. While black and South-Asian migrants are clearly disadvantaged in their job quality, white migrants are more polarised with high probabilities of working on high quality jobs as well as bad jobs. Importantly, UK-born Pakistani and Bangladeshi workers do consistently worse in terms of the quality of their work, and they, together with South-Asian and black migrants occupy the bottom of the ethnic hierarchy. We further find ethnic differences in middling jobs with Indian, Pakistani and Bangladeshi UK-born minorities as well as South-Asian migrants on average more likely to work on the high intrinsic/low rewards jobs - jobs which combine high job satisfaction and autonomy with low monetary rewards and unsociable hours. Black UK-born and migrant workers are somewhat more likely to work on the unhappy 9 to 5 jobs and the polarized jobs - more stable jobs which have good monetary rewards but bring little intrinsic satisfaction. These differences highlight the importance of considering multi-dimensional job quality.

[Figure 2 about here]

While UK-born white women are much less likely to work on high quality jobs than UK-born white men, these differences are substantially smaller among all UK-born ethnic minorities and even reversed for black Caribbean workers where women are much more likely to work in these desirable conditions. On the other hand, Bangladeshi UK-born women are substantially more likely than their male counterparts to work on bad jobs, although the over-representation of women in these lowquality positions is again smaller for the other UK-born ethnic minorities than among UK-born whites. These differences are in line with previous work showing smaller gender gaps among working ethnic minorities than among the majority (Brynin et al., 2017). One possible reason for this could be a higher selection into work among certain groups. We address this in the robustness tests by estimating a Heckman selection model, finding few differences when accounting for selection. 
Accepted version. Published as: Zwysen \& Demireva (2018). Ethnic and migrant penalties in job quality in the UK: the role of residential concentration and occupational clustering, Journal of Ethnic and Migration Studies.

In a next step we test what drives the ethnic hierarchy in status attainment by modelling class membership and sequentially adding explanatory variables. Figure 3 and Figure 4 show the estimated AME's by origin compared to UK-born whites. Full results are shown in Table A2 and Table A3 in the supplementary material, as marginal predicted probabilities, for all variables included.

[Figure 3 about here]

UK-born Pakistani and Bangladeshi men are significantly less likely to work on high-quality jobs than UK-born white men with Pakistanis more likely to work on bad jobs and both more likely, albeit not statistically significantly so $(\mathrm{p}<0.05)$ to work on unhappy 9 to 5 jobs. South-Asian and black migrants (foreign-born) work more on bad jobs than white British and are less likely to work on highquality jobs, while South-Asian migrants are more likely to work on high intrinsic/low rewards jobs and black migrants less likely. White migrants, and UK-born Indian and black minorities are on average not much different from their white UK-born counterparts in job quality.

Including socio-demographic characteristics (SD) ${ }^{22}$ does account for some of the disadvantage of Bangladeshi UK-born men, although they remain significantly less likely than their UK-born white counterparts to work on high-quality jobs $(\mathrm{p}<0.05)$. Compared to similar UK-born whites, UK-born Indian and all migrant groups are shown to be statistically significantly $(p<0.05)$ less likely to work on high-quality jobs. This indicates they have relatively strong socio-demographic profiles compared to UK-born white workers which masks disadvantage when only comparing averages, as also found when studying ethnic penalties in earnings (Dustmann and Theodoropoulos, 2010).

\footnotetext{
${ }^{22}$ Higher qualifications increase the probability of working on high-quality jobs and are negatively related to working on high intrinsic/low rewards and bad jobs. Having a dependent child reduces the probability of working on high-quality jobs and increases working on high intrinsic/low rewards and bad jobs, but only for women. Cohabiting is positively related to working on high-quality jobs and negatively to bad jobs, as is age which also reduces working on high intrinsic/low rewards job. In the South-East high-quality and polarized jobs for men and unhappy 9 to 5 jobs for women are more likely while high intrinsic/low rewards and bad jobs are less likely. Highquality jobs are more likely in urban areas and high intrinsic/low rewards jobs less likely.
} 
Accepted version. Published as: Zwysen \& Demireva (2018). Ethnic and migrant penalties in job quality in the UK: the role of residential concentration and occupational clustering, Journal of Ethnic and Migration Studies.

The next model includes information on overall deprivation, resources and diversity in the locality ${ }^{23}$. Living in areas with fewer opportunities explains some of the disadvantage of UK-born Pakistani and Bangladeshi minorities. When comparing them to UK-born whites in similar localities Pakistani men are no longer significantly $(\mathrm{p}<0.05)$ more likely to work on bad jobs, and somewhat more likely to work on high intrinsic/low rewards jobs; while Bangladeshi men are no longer significantly less likely to work on high-quality jobs than similar whites. Including these controls further reduces the lower probability of working on high intrinsic/low rewards jobs for black migrants and renders it no longer statistically significantly different from UK-born whites $(p<0.05)$. Thus, living in areas with worse opportunities and resources drives some of the working in bad jobs for UK-born Pakistani and Bangladeshi men as well as the employment in jobs with low monetary rewards for black migrants.

In the final model ethnic minorities and migrants are compared to their counterparts with similar socio-demographic characteristics, living in similar localities, and working in the same sector, firm size, occupational group, with the same exposure to migrants ${ }^{24}$. This specification reduces the disadvantage of migrant groups in reaching high-quality jobs substantially while also reducing the likelihood of working on bad jobs. The difference between white migrants and the majority in working on high-quality jobs is no longer statistically significant.

\footnotetext{
${ }^{23}$ The overall employment rate in the locality and diversity is positively associated with working on high-quality jobs while a higher employment rate reduces the probability of working on bad jobs. For women the employment rate only reduces the risk of working on bad jobs, while the share of professional/managerial residents matters more for the probability of working on high-quality jobs and reduces the likelihood of working on high intrinsic/low rewards jobs.

${ }^{24}$ Working in the public sector is associated with more polarized and unhappy 9 to 5 work, while reducing the probability of all-around high-quality as well as bad jobs. Working in larger firms is associated with more highquality, more polarized and more unhappy 9 to 5 jobs; while the probability of working on bad jobs is lower in firms with more than 100 employees, and working on high intrinsic/low rewards jobs is most likely in small firms. Working in an occupation with more migrants is on average associated with a lower probability of working on high-quality jobs and more high intrinsic/low rewards jobs. Job quality is also related to large occupational sectors, with high-quality work most likely in legislator/managerial positions, high intrinsic/low rewards jobs least likely in professional and technician jobs; polarized jobs most likely among skilled agricultural and plant/machine for men and professional jobs for women; unhappy 9 to 5 most common among clerks; and bad jobs most present in elementary occupations.
} 
Accepted version. Published as: Zwysen \& Demireva (2018). Ethnic and migrant penalties in job quality in the UK: the role of residential concentration and occupational clustering, Journal of Ethnic and Migration Studies.

[Figure 4 about here]

Patterns differ among women (Figure 4). There is little difference between UK-born ethnic minority women and their UK-born white counterparts, with only black Caribbean women standing out as being significantly more likely to work on high-quality jobs and less likely to work on high intrinsic/low rewards and bad jobs; and black African women as also less likely to work on high intrinsic/low rewards jobs. The difference of black Caribbean women compared to their white British counterparts is reduced when including socio-demographic characteristics indicating that positive compositional effects on their behalf explain the lower likelihood of finding them in bad jobs.

South-Asian and black migrant women are still estimated to be less likely to work on high-quality jobs than white UK-born women, with South-Asian migrant women more likely to work on bad jobs and black migrant women more likely to work on polarized jobs. White migrant women on the other hand are somewhat more likely to work on high-quality jobs. Accounting for their socio-demographic characteristics explains away the advantage of white migrant women and shows they are more likely to work on bad jobs, similarly to South-Asian and black migrant women. Migrants' worse job quality is then to some extent explained by including occupational characteristics although a significant difference remains for south-Asian migrant women and white migrant women.

Our findings confirm previous studies, while also highlighting the importance of considering different aspects of job quality as the drivers of not working on high quality positions are not the same as those for working on bad jobs for instance. Accounting for socio-demographic differences serves to highlight ethnic differences as migrants and UK-born minorities have quite competitive profiles and would be expected to work on better quality positions, if these were rewarded as they are for the white majority (Dustmann and Theodoropoulos, 2010; Heath and Cheung, 2006). For male UK-born South-Asian workers we find the local area constrains their access to high-quality jobs which could indicate these groups being separated from the best jobs (Feng et al., 2015; Hellerstein et al., 2008). 
Accepted version. Published as: Zwysen \& Demireva (2018). Ethnic and migrant penalties in job quality in the UK: the role of residential concentration and occupational clustering, Journal of Ethnic and Migration Studies.

Migrants in the UK further seem to be strongly segregated into occupations with worse conditions, while this is not so much the case for ethnic minorities (Elliott and Lindley, 2008).

\subsection{Spatial mismatch and network effects}

To better understand the importance of local area and occupational characteristics for different ethnic groups we estimate models allowing local area and occupational factors to vary ethnicity and migrant status. Table 3 and Table 4 present the AME of a 1-unit increase in each of four contextual variables on job quality, estimated through separate models interacting resp. the share of co-ethnics in the local area, the employment rate among co-ethnics in the local area, the exposure to migrants and the exposure to co-ethnics in the occupation, with origin. These coefficients then indicate how a change in local and occupational characteristics affects each of the groups in terms of their probability of falling into a job quality category.

Among men (Table 3), white UK-born workers living in an area with more other whites are somewhat more likely to work on high intrinsic/low rewards types jobs and less likely to work on polarized jobs. White migrants as well as Indian and Pakistani UK-born workers who live in an area with more co-ethnics benefit from this as they are less likely to work on bad jobs, although this is not statistically significant $(p<0.1)$ for Pakistani workers. Indian and Pakistani UK-born workers are more likely to work on high intrinsic/low rewards jobs if living in an area with more co-ethnics. On the other hand, black Caribbeans living in areas with more co-ethnics are less likely to access high-quality or the stable well-paid polarized jobs; black African UK-born workers less likely to work unhappy 9 to 5 jobs; and Pakistani UK-born workers more likely to work on high intrinsic/low quality jobs. We find that living among co-ethnics does not really benefit black minorities who become less likely to occupy the stable middling positions.

[Table 3 about here] 
Accepted version. Published as: Zwysen \& Demireva (2018). Ethnic and migrant penalties in job quality in the UK: the role of residential concentration and occupational clustering, Journal of Ethnic and Migration Studies.

Rather than the share of co-ethnics, their resources may be crucial in affecting job quality. We therefore consider the employment rate among co-ethnics and show it matters strongly in protecting UK-born Indian, black Caribbean and black African workers as well as south-Asian migrants, from working on bad jobs. Black Caribbean workers are also more likely to work on high-quality jobs if the co-ethnic network has a higher employment rate. Overall the employment rate of co-ethnics brings about an important boost in the job quality of minority members, and signifies that ethnic networks are important when they constitute part of a healthy economic environment.

At the occupational level we include the exposure to migrants as a measure of possible competition and to test fears of undercutting. White UK-born workers are somewhat affected by the exposure to migrants. For example, when working in an occupation with twice as many migrants as would be expected they are $2 \%$-points less likely to work in high quality jobs and $2 \%$-points more likely to work on high intrinsic/low rewards jobs - middling jobs with lower pay. The competition is particularly fierce among migrants however. South-Asian migrants are $7 \%$-points less likely and white and black migrants $10-11 \%$-points less likely to work on high-quality jobs when they are exposed to a lot of other migrants in the occupation. Moreover, white and South-Asian migrants are more likely to work on bad jobs when migrants are over-represented in their occupation, while black migrants mainly move to polarized jobs. Among the UK-born minorities, the probability of black Caribbeans to work on high-quality jobs is also strongly and negatively affected. The effect of co-ethnics in an occupation is similarly negative. This could indicate that the jobs found through occupational ethnic networks are of lower quality. The working conditions of UK-born Bangladeshi, black Caribbean and black Africans, as well as those of South-Asian migrants decline in occupations with high share of co-ethnics and their probability of working on bad jobs increases.

[Table 4 about here]

Among women (Table 4) living in an area with more co-ethnics is associated with a higher probability of working on bad jobs for Pakistani UK-born women and South-Asian migrants, and more 
Accepted version. Published as: Zwysen \& Demireva (2018). Ethnic and migrant penalties in job quality in the UK: the role of residential concentration and occupational clustering, Journal of Ethnic and Migration Studies.

unhappy 9 to 5 jobs for Bangladeshi women. The employment rate among co-ethnics is also associated with a higher probability of working on high-quality jobs for Pakistani women, but for Bangladeshi women it is associated with a higher rate of working on bad jobs and a reduction of high intrinsic/low rewards and unhappy 9 to 5 jobs. The benefits of local area networks can then be limited for Pakistani and Bangladeshi women and may lead to worse jobs, although for Pakistani women this depends on the resources within the community. Working in an occupation with more co-ethnics is not strongly related to the quality of work for women, but can shield more vulnerable minority women from working on bad jobs or jobs with less monetary rewards. White UK-born women are somewhat more likely to work unhappy 9 to 5 jobs rather than polarized jobs when working with more co-ethnics; while white migrants are less likely to work in polarized jobs. Pakistani women are less likely to work on high intrinsic/low rewards jobs as are black Caribbean UK-born, and black African UK-born are less likely to work on bad jobs.

\subsection{Sensitivity test: selection into work}

Migrants and minorities who work may be a more selective group than working UK-born whites, therefore biasing our results of the disadvantage they face on the labour market by only including the employed. This selection may be especially important for women and explain the rather small differences by origin and migration status as well as the limited effect of local area on job quality, if most differentiation happens prior to working in the first place.

We therefore estimate a Heckman selection model on job quality to account for this selection into work, by estimating a linear probability model for belonging to each of the 5 latent class outcomes as well as a selection equation predicting whether respondents were working and reported job quality characteristics, restricted to those who report being employed, unemployed or inactive, but not in education/training nor retired. Thee residuals of both equations can correlate. Cohabiting and having a dependent child were left out of the outcome equation and used in the selection equation, together 
Accepted version. Published as: Zwysen \& Demireva (2018). Ethnic and migrant penalties in job quality in the UK: the role of residential concentration and occupational clustering, Journal of Ethnic and Migration Studies.

with an indicator of religion ${ }^{25}$. Both selection equation and the job quality equations further include socio-demographic information and information on region, urbanity, local area and year of survey.

[Table 5 about here]

The results, shown in Table 5, are very similar on most outcomes, but do indicate that accounting for selection reduces the over-representation of migrants into bad jobs, indicating they are more likely to take any job - including bad ones - than are white UK-born men. Similarly, Indian, Pakistani and Bangladeshi men would be less likely to be on bad jobs if they had similar selection to UK-born whites. UK-born Indian and Bangladeshi women would be expected to work less on bad jobs than white British if they had similar selection into work. This indicates that while there are differences of selection into work, it seems to be that minority men and women and especially migrant men are more likely to take up even bad jobs rather than not working than the white British.

\section{Discussion}

In this paper we set out a new way to study ethnic inequalities in multidimensional job quality in the UK, comparing migrants and ethnic minorities to the white UK-born on clusters of 17 job quality indicators. We show that most UK-born minorities are less likely than their UK-born white counterparts to work on high-quality jobs - which provide good monetary rewards, high work-life balance, high intrinsic satisfaction and good job security - than their UK-born white counterparts, but the patterns of disadvantage differ along several dimensions. This variation in type of job is important as it indicates ethnic differences in work-life balance, security and income, which would not be captured by using a one-dimensional measure of job quality.

We find that migrants, particularly non-white, are indeed more likely to work on worse quality jobs compared to their UK-born counterparts. They are more likely to work in bad jobs - with precarious positions with fewer benefits and worse job security. Interestingly, most UK-born ethnic

\footnotetext{
${ }^{25} 8$ categories: no religion; Christian; Muslim; Hindu; Jewish; Sikh; Buddhist; other
} 
Accepted version. Published as: Zwysen \& Demireva (2018). Ethnic and migrant penalties in job quality in the UK: the role of residential concentration and occupational clustering, Journal of Ethnic and Migration Studies.

minority women do as well or better than UK-born white women, supporting previous findings that gender inequalities strongly differ by ethnicity in the UK.

These differences in job quality are partially driven by contextual factors: the strong disadvantage of UK-born Pakistani and Bangladeshi men is mainly driven by their concentration in more deprived localities with fewer opportunities. We further find that the presence of co-ethnics, particularly when accompanied by higher employment rates within the co-ethnic community indicating stronger resources, can have a shielding effect and protect South-Asian minorities and migrants from working on the lowest-quality jobs. While the share of co-ethnics does not improve outcomes for black workers, they - as well as Indians - are sheltered from working on the worst jobs when living in a locality where the own ethnic group has a higher employment rate - indicating they can provide support in job search. This supports previous research on the protective effects of minority niches, particularly when facing discrimination and strong disadvantage. Importantly, the observed patterns are not consistent with concerns among policy makers that minorities living in a strong co-ethnic environment are doomed to the worst jobs.

Finally, the low job quality of migrants is strongly driven by the occupations in which they work. While minorities may be more likely to find work in occupations in which more co-ethnics already work, meaning they can rely on ethnic networks for job search, these jobs tend to be very lowquality, with worse work-life balance, lower pay, lower security and less intrinsic quality.

Working in occupations with a higher share of migrants is negatively associated with job quality, but pronouncedly so for other migrants and UK-born black Caribbeans. We find that UK-born whites are also somewhat less likely to work on the best conditions when working in occupations with a higher share of migrants, although the effect is very small. Thus, a high share of migrants can be associated with greater competition for UK-born whites for the best jobs but concerns on undercutting of work conditions should be extended primarily to the situation of established minority groups and 
Accepted version. Published as: Zwysen \& Demireva (2018). Ethnic and migrant penalties in job quality in the UK: the role of residential concentration and occupational clustering, Journal of Ethnic and Migration Studies.

migrants. After all, one should keep in mind that most UK-born whites do not work in occupations with high presence of migrants unlike UK-born minorities and especially migrants. 
Accepted version. Published as: Zwysen \& Demireva (2018). Ethnic and migrant penalties in job quality in the UK: the role of residential concentration and occupational clustering, Journal of Ethnic and Migration Studies.

\section{References}

Anderson, B. (2010). Migration, immigration controls and the fashioning of precarious workers. Work Employment Society 24, 300-317.

Aslund, O., and Skans, O. (2010). Will i see you at work? Ethnic workplace segregation in sweden, 1985-2002. ILR Review 63.

Battu, H., and Sloane, P.J. (2004). Over-education and ethnic minorities in Britain. The Manchester School 72, 535-559.

Battu, H., Seaman, P., and Zenou, Y. (2011). Job contact networks and the ethnic minorities. Labour Economics 18, 48-56.

Bayer, P., Ross, S.L., and Topa, G. (2008). Place of work and place of residence: informal hiring networks and labor market outcomes. Journal of Political Economy 116, 1150-1196.

Blackaby, D.H., Leslie, D.G., Murphy, P.D., and O'Leary, N.C. (2005). Born in Britain: How are native ethnic minorities faring in the British labour market? Economics Letters 88, 370-375.

Boeri, T., De Philippis, M., Patacchini, E., and Pellizzari, M. (2015). Immigration, Housing Discrimination and Employment. Econ J 125, F82-F114.

Brynin, M., and Guveli, A. (2012). Understanding the ethnic pay gap in Britain. Work, Employment \& Society 26, 574-587.

Brynin, M., Longhi, S., and Zwysen, W. (2017). The diversification of inequality. The British Journal of Sociology 0.

Casey, L. (2016). The Casey Review: a review into opportunity and integration (London, UK: Department for Communities and Local Government).

Cheung, S.Y. (2013). Ethno-religious minorities and labour market integration: generational advancement or decline? Ethnic and Racial Studies 37, 140-160.

Clark, A.E. (2001). What really matters in a job? Hedonic measurement using quit data. Labour Economics 8, 223-242.

Corbyn, J. (2017). Speech in Peterborough, January 10, 2017 (Peterborough, UK).

Datta, K., Mcllwaine, C., Evans, Y., Herbert, J., May, J., and Wills, J. (2007). From Coping Strategies to Tactics: London's Low-Pay Economy and Migrant Labour. British Journal of Industrial Relations 45, 404-432.

Demireva, N., and Kesler, C. (2011). The curse of inopportune transitions: the labour market behaviour of immigrants and natives in the uk. International Journal of Comparative Sociology 52, 306-326.

Duleep, H.O., and Regets, M.C. (1997). The decline in immigrant entry earnings: Less transferable skills or lower ability? Quarterly Review of Economics \& Finance 37, 189. 
Accepted version. Published as: Zwysen \& Demireva (2018). Ethnic and migrant penalties in job quality in the UK: the role of residential concentration and occupational clustering, Journal of Ethnic and Migration Studies.

Dustmann, C., and Theodoropoulos, N. (2010). Ethnic minority immigrants and their children in Britain. Oxford Economic Papers 62, 209-233.

Dustmann, C., Glitz, A., and Schonberg, U. (2016). Referral-based job search networks. The Review of Economic Studies 83, 514-546.

Edin, P.-A., Fredriksson, P., and Åslund, O. (2003). Ethnic enclaves and the economic success of immigrants: evidence from a natural experiment. The Quarterly Journal of Economics 118, 329-357.

Elliott, R.J.R., and Lindley, J.K. (2008). Immigrant wage differentials, ethnicity and occupational segregation. Journal of the Royal Statistical Society: Series A (Statistics in Society) 171, 645-671.

Feng, X., Flowerdew, R., and Feng, Z. (2015). Does neighbourhood influence ethnic inequalities in economic activity? Findings from the ONS Longitudinal Study. Journal of Economic Geography 15, 169-194.

Frijters, P., Shields, M.A., and Price, S.W. (2005). Job search methods and their success: a comparison of immigrants and natives in the UK. The Economic Journal 115, F359-F376.

Heath, A., and Cheung, S.Y. (2006). Ethnic penalties in the labour market: Employers and discrimination (London, UK: Department for Work and Pensions).

Hellerstein, J.K., Neumark, D., and Mclnerney, M. (2008). Spatial mismatch or racial mismatch? Journal of Urban Economics 64, 464-479.

Jencks, C., Perman, L., and Rainwater, L. (1988). What is a good job? A new measure of labor-market success. American Journal of Sociology 93, 1322-1357.

Jivraj, S., and Simpson, L. (2015). How has ethnic diversity grown? In Ethnic Identity and Inequalities in Britain, S. Jivraj, and L. Simpson, eds. (Bristol, UK: Policy Press), pp. 19-31.

Knies, G. (2017). Understanding Society: The UK Household Longitudinal Study, Waves 1-7, User Guide (Colchester, UK: Institute for Social and Economic Research, University of Essex).

Lancee, B. (2016). Job search methods and immigrant earnings: a longitudinal analysis of the role of bridging social capital. Ethnicities 16, 349-367.

Lanza, S.T., Dziak, J.J., Huang, L., Wagner, A.T., and Collins, L.M. (2015). LCA Stata Plugin Users' Guide Version 1.2 (University Park: The Methodology Center, Penn State: Penn State).

Leschke, J., Watt, A., and Finn, M. (2012). Job quality in the crisis - an update of the Job Quality Index (JQI) (Brussels, Belgium: European Trade Union Institute).

Lewis, J.B., and Linzer, D.A. (2005). Estimating regression models in which the dependent variable is based on estimates. Political Analysis 13, 345-364.

Li, Y., and Heath, A. (2008). Minority ethnic men in british labour market (1972-2005). Int J of Soc \& Social Policy 28, 231-244.

Li, Y., and Heath, A. (2016). Class matters: A study of minority and majority social mobility in Britain, 1982-2011. American Journal of Sociology 122, 162-200. 
Accepted version. Published as: Zwysen \& Demireva (2018). Ethnic and migrant penalties in job quality in the UK: the role of residential concentration and occupational clustering, Journal of Ethnic and Migration Studies.

Lindley, J. (2009). The over-education of UK immigrants and minority ethnic groups: Evidence from the Labour Force Survey. Economics of Education Review 28, 80-89.

Mcdowell, L., Batnitzky, A., and Dyer, S. (2009). Precarious Work and Economic Migration: Emerging Immigrant Divisions of Labour in Greater London's Service Sector. International Journal of Urban and Regional Research 33, 3-25.

Muñoz de Bustillo, R., Fernández-Macías, E., Antón, J.-I., and Esteve, F. (2011). Measuring more than money: the social economics of job quality (Cheltenham, U.K.; Northampton, Mass.: Edward Elgar).

Patacchini, E., and Zenou, Y. (2012). Ethnic networks and employment outcomes. Regional Science and Urban Economics 42, 938-949.

Ryan, L. (2007). Migrant Women, Social Networks and Motherhood: The Experiences of Irish Nurses in Britain. Sociology 41, 295-312.

Schaeffer, M. (2014). Ethnic diversity and social cohesion (Surrey, England: Ashgate Publishing Limited).

Semyonov, M., and Herring, C. (2007). Segregated jobs or ethnic niches?: the impact of racialized employment on earnings inequality. Research in Social Stratification and Mobility 25, 245-257.

Simpson, L., and Finney, N. (2010). Parallel lives and ghettos in Britain: facts or myths? Geography 95, 124-131.

Simpson, L., Warren, J., and Jivraj, S. (2015). Do people change their ethnicity over time? In Ethnic Identity and Inequalities in Britain, S. Jivraj, and L. Simpson, eds. (Bristol, UK: Policy Press), pp. 79-92.

Vermunt, J.K., and Magidson, J. (2002). Latent Class Cluster Analysis. In Applied Latent Class Analysis, J.A. Hagenaars, and A.L. McCutcheon, eds. (Cambridge, UK: Cambridge University Press), pp. 89-106.

White, N. (2017). Migration Statistics Quarterly Report: November 2017 (ONS).

Zuccotti, C.V., and Platt, L. (2016). Does Neighbourhood Ethnic Concentration in Early Life Affect Subsequent Labour Market Outcomes? A Study across Ethnic Groups in England and Wales. Popul. Space Place n/a-n/a. 
Accepted version. Published as: Zwysen \& Demireva (2018). Ethnic and migrant penalties in job quality in the UK: the role of residential concentration and occupational clustering, Journal of Ethnic and Migration Studies.

\section{List of tables}

Table 1: Overview of selection of latent classes

\begin{tabular}{|c|c|c|c|c|c|c|c|c|c|}
\hline class & & $\begin{array}{l}\text { LL vs } \\
\text { saturated }\end{array}$ & $\begin{array}{l}\text { p-value } \\
\text { difference } \\
\text { saturated }\end{array}$ & & $\begin{array}{l}\text { Log } \\
\text { likelihood } \\
\text { model } \\
\end{array}$ & df & & $\mathrm{AIC}$ & BIC \\
\hline & 1 & 179894.1 & & 0 & -808499 & & 17 & 1617031 & 1617190 \\
\hline & 2 & 117071.7 & & 1 & -777087 & & 35 & 1554245 & 1554572 \\
\hline & 3 & 95681.35 & & 1 & -766392 & & 53 & 1532890 & 1533386 \\
\hline & 4 & 86102.33 & & 1 & -761603 & & 70 & 1523345 & 1523999 \\
\hline & 5 & 75119.81 & & 1 & -756111 & & 89 & 1512401 & 1513232 \\
\hline & 6 & 71170.96 & & 1 & -754137 & & 106 & 1508486 & 1509476 \\
\hline & 7 & 69470.46 & & 1 & -753287 & & 121 & 1506815 & 1507946 \\
\hline
\end{tabular}

Shows goodness-of-fit statistics for latent class analysis, estimated using stata's gsem routine, with log-likelihood of model

and test compared to the saturated model, including the AIC and BIC. 
Accepted version. Published as: Zwysen \& Demireva (2018). Ethnic and migrant penalties in job quality in the UK: the role of residential concentration and occupational clustering, Journal of Ethnic and Migration Studies.

Table 2: class membership and posterior probability by class

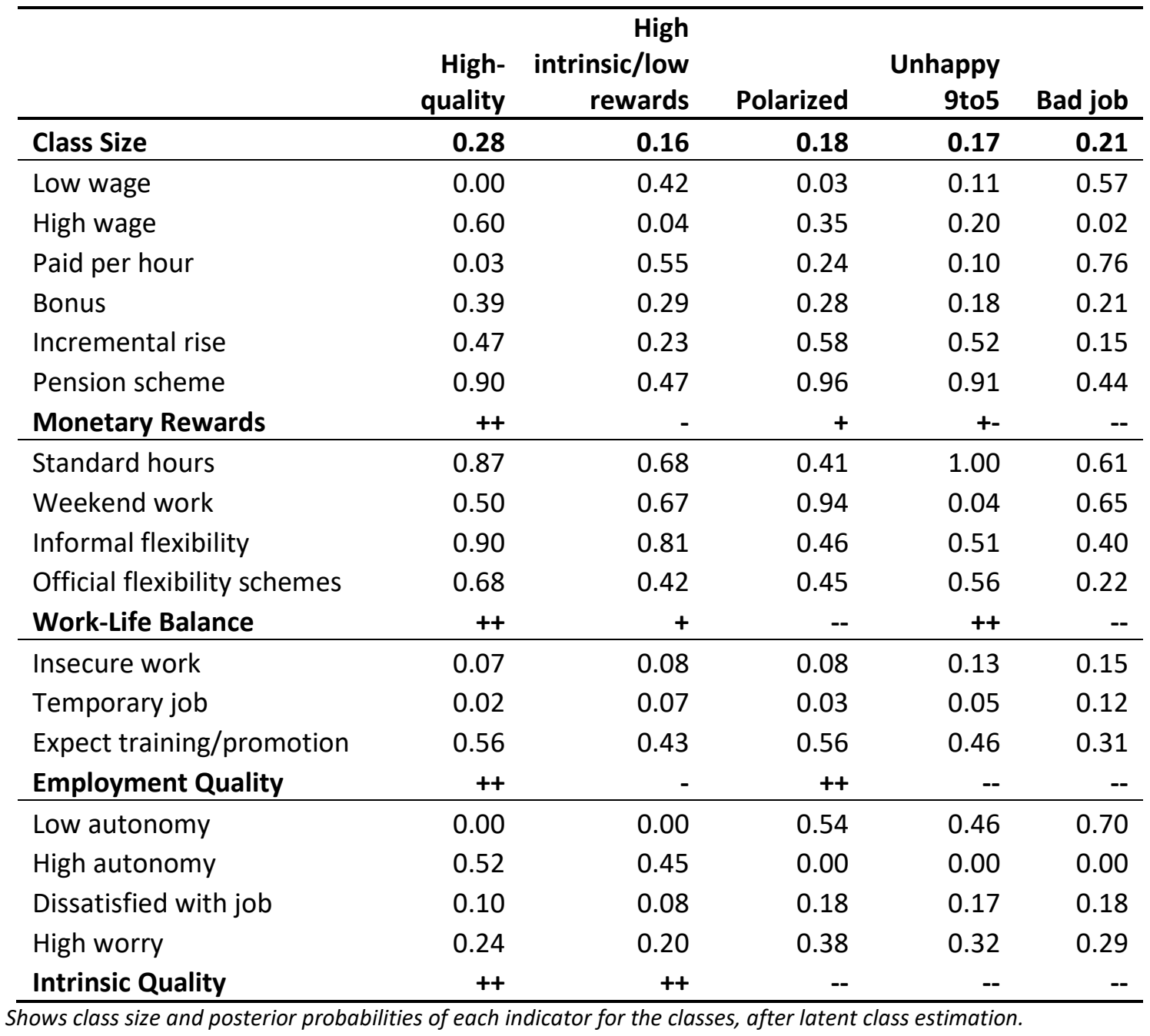


Accepted version. Published as: Zwysen \& Demireva (2018). Ethnic and migrant penalties in job quality in the UK: the role of residential concentration and occupational clustering, Journal of Ethnic and Migration Studies.

Table 3: Effect of local and occupational composition on job quality: men

\begin{tabular}{|c|c|c|c|c|c|c|}
\hline & Men $(\mathrm{N}=30,121)$ & High-quality & $\begin{array}{c}\text { High } \\
\text { intrinsic/low } \\
\text { rewards } \\
\end{array}$ & Polarized & $\begin{array}{c}\text { Unhappy } \\
\text { 9to5 }\end{array}$ & Bad job \\
\hline \multirow{9}{*}{$\begin{array}{l}\text { Share co- } \\
\text { ethnics } \\
\text { (local) }\end{array}$} & white UK-born & -0.013 & $0.070^{*}$ & $-0.089^{\star *}$ & 0.006 & 0.026 \\
\hline & white migrant & 0.062 & -0.032 & 0.040 & 0.032 & $-0.101^{* * *}$ \\
\hline & Indian UK-born & -0.005 & $0.383^{\star *}$ & -0.041 & -0.038 & $-0.299^{* *}$ \\
\hline & Pakistani UK-born & -0.255 & $0.391^{* \star *}$ & -0.022 & 0.079 & -0.193 \\
\hline & Bangladeshi UK-born & 0.155 & 0.090 & -0.342 & 0.005 & 0.091 \\
\hline & South-Asian migrant & 0.121 & -0.014 & -0.089 & -0.045 & 0.026 \\
\hline & black Caribbean UK-born & $-0.822^{* \star \star}$ & 0.557 & $-0.448^{* *}$ & 0.067 & 0.646 \\
\hline & black African UK-born & 0.175 & 0.036 & 0.401 & $-0.503^{* * *}$ & -0.109 \\
\hline & black migrant & 0.223 & 0.190 & -0.263 & -0.114 & -0.036 \\
\hline \multirow{9}{*}{$\begin{array}{l}\text { Employment } \\
\text { rate co- } \\
\text { ethnics } \\
\text { (local) }\end{array}$} & white UK-born & 0.526 & -0.198 & $-0.481^{*}$ & 0.151 & 0.001 \\
\hline & white migrant & -0.076 & -0.289 & -0.161 & 0.193 & 0.333 \\
\hline & Indian UK-born & -0.000 & 0.621 & 0.426 & 0.022 & $-1.069^{* *}$ \\
\hline & Pakistani UK-born & 0.493 & $-1.419^{\star * *}$ & 0.387 & -0.227 & 0.766 \\
\hline & Bangladeshi UK-born & -0.471 & 0.779 & -1.121 & -0.221 & 1.033 \\
\hline & South-Asian migrant & 0.450 & 0.490 & $-0.515^{\star}$ & 0.234 & $-0.659^{* *}$ \\
\hline & black Caribbean UK-born & $1.755^{* *}$ & -0.361 & -0.386 & $-0.450^{* *}$ & $-0.558^{* *}$ \\
\hline & black African UK-born & 0.108 & -0.096 & -0.037 & 0.648 & $-0.624^{* * *}$ \\
\hline & black migrant & -0.142 & -0.050 & $-0.443^{* *}$ & 0.840 & -0.205 \\
\hline \multirow{9}{*}{$\begin{array}{l}\text { Exposure to } \\
\text { migrants in } \\
\text { occupation } \\
(\log )\end{array}$} & white UK-born & $-0.018^{* *}$ & $0.019^{* \star *}$ & 0.003 & -0.006 & 0.002 \\
\hline & white migrant & $-0.097^{\star * \star}$ & 0.014 & 0.015 & -0.009 & $0.076^{\star \star *}$ \\
\hline & Indian UK-born & -0.056 & 0.031 & 0.009 & -0.013 & 0.029 \\
\hline & Pakistani UK-born & 0.045 & 0.062 & -0.053 & -0.028 & -0.027 \\
\hline & Bangladeshi UK-born & 0.013 & 0.030 & -0.064 & 0.019 & 0.001 \\
\hline & South-Asian migrant & $-0.069^{* *}$ & -0.018 & 0.032 & -0.033 & $0.087^{* * *}$ \\
\hline & black Caribbean UK-born & $-0.125^{*}$ & 0.072 & 0.071 & -0.090 & 0.071 \\
\hline & black African UK-born & -0.051 & 0.076 & 0.077 & $-0.172^{*}$ & 0.070 \\
\hline & black migrant & $-0.109^{* *}$ & 0.003 & $0.135^{\star \star}$ & -0.038 & 0.009 \\
\hline \multirow{9}{*}{$\begin{array}{l}\text { Exposure to } \\
\text { co-ethnics in } \\
\text { occupation } \\
\text { (log) }\end{array}$} & white UK-born & -0.032 & -0.011 & 0.060 & -0.042 & 0.026 \\
\hline & white migrant & 0.219 & 0.091 & -0.104 & -0.020 & -0.185 \\
\hline & Indian UK-born & -0.053 & -0.017 & 0.000 & $0.063^{\star \star}$ & 0.007 \\
\hline & Pakistani UK-born & 0.037 & 0.008 & -0.051 & 0.016 & -0.010 \\
\hline & Bangladeshi UK-born & -0.034 & 0.028 & -0.039 & -0.016 & $0.062^{* \star *}$ \\
\hline & South-Asian migrant & -0.030 & -0.006 & 0.013 & -0.015 & $0.038^{\star \star *}$ \\
\hline & black Caribbean UK-born & -0.098 & 0.044 & -0.058 & $-0.070^{*}$ & $0.183^{\star \star \star}$ \\
\hline & black African UK-born & $-0.173^{\star *}$ & -0.058 & 0.037 & -0.008 & $0.202^{* *}$ \\
\hline & black migrant & -0.031 & -0.004 & 0.048 & -0.046 & 0.032 \\
\hline
\end{tabular}

${ }^{* * *} p<0.01,{ }^{* *} p<0.05, * p<0.1$, showing estimated effect of 1-unit increase in a contextual factor on the average probability of class membership by ethnicity and migrant status, estimated from multinomial logistic regression models in which each contextual factor is interacted separately with ethnicity and migrant status, controlling for socio-demographic characteristics, local area characteristics, sector and occupational characteristics. 
Accepted version. Published as: Zwysen \& Demireva (2018). Ethnic and migrant penalties in job quality in the UK: the role of residential concentration and occupational clustering, Journal of Ethnic and Migration Studies.

Table 4: Effect of local and occupational composition on job quality: women

\begin{tabular}{|c|c|c|c|c|c|c|}
\hline & Women $(\mathrm{N}=38,271)$ & High-quality & $\begin{array}{c}\text { High } \\
\text { intrinsic/low } \\
\text { rewards } \\
\end{array}$ & Polarized & $\begin{array}{c}\text { Unhappy } \\
\text { 9to5 }\end{array}$ & Bad job \\
\hline \multirow{9}{*}{$\begin{array}{l}\text { Share co- } \\
\text { ethnics } \\
\text { (local) }\end{array}$} & white UK-born & 0.005 & 0.000 & -0.020 & -0.014 & 0.030 \\
\hline & white migrant & 0.052 & -0.039 & -0.028 & -0.017 & 0.033 \\
\hline & Indian UK-born & -0.235 & -0.117 & 0.040 & 0.306 & 0.006 \\
\hline & Pakistani UK-born & -0.169 & -0.215 & 0.036 & 0.114 & $0.234^{* *}$ \\
\hline & Bangladeshi UK-born & 0.135 & 0.240 & -0.368 & $0.255^{\star *}$ & -0.261 \\
\hline & South-Asian migrant & -0.124 & -0.016 & -0.123 & 0.101 & $0.162^{*}$ \\
\hline & black Caribbean UK-born & 0.050 & -0.270 & -0.211 & 0.753 & -0.322 \\
\hline & black African UK-born & -0.271 & -0.094 & -0.038 & 0.138 & 0.265 \\
\hline & black migrant & -0.153 & 0.145 & -0.090 & 0.005 & 0.094 \\
\hline \multirow{9}{*}{$\begin{array}{l}\text { Employment } \\
\text { rate co- } \\
\text { ethnics } \\
\text { (local) }\end{array}$} & white UK-born & 0.276 & -0.364 & -0.036 & -0.056 & 0.180 \\
\hline & white migrant & -0.271 & -0.364 & 0.100 & 0.343 & 0.192 \\
\hline & Indian UK-born & -0.034 & -0.336 & -0.232 & 0.530 & 0.072 \\
\hline & Pakistani UK-born & $1.250^{*}$ & -0.509 & -0.205 & -0.842 & 0.305 \\
\hline & Bangladeshi UK-born & 0.193 & $-1.342^{* \star *}$ & 0.031 & $-0.700^{* * *}$ & $1.817^{\star}$ \\
\hline & South-Asian migrant & 0.328 & 0.140 & 0.019 & -0.063 & -0.423 \\
\hline & black Caribbean UK-born & -0.123 & 0.092 & -0.026 & -0.232 & 0.289 \\
\hline & black African UK-born & 0.386 & -0.179 & $-0.851^{*}$ & 0.373 & 0.270 \\
\hline & black migrant & 0.308 & -0.133 & 0.123 & $-0.312^{*}$ & 0.014 \\
\hline \multirow{9}{*}{$\begin{array}{l}\text { Exposure to } \\
\text { migrants in } \\
\text { occupation } \\
\text { (log) }\end{array}$} & white UK-born & $-0.030^{* * *}$ & $0.015^{\star *}$ & $0.058^{* * *}$ & $-0.058^{* * *}$ & $0.016^{\star * *}$ \\
\hline & white migrant & $-0.077^{* * *}$ & -0.004 & 0.047 & -0.047 & $0.080^{* * *}$ \\
\hline & Indian UK-born & 0.055 & 0.010 & 0.035 & -0.061 & -0.040 \\
\hline & Pakistani UK-born & -0.034 & 0.075 & $0.100^{*}$ & -0.028 & $-0.113^{\star *}$ \\
\hline & Bangladeshi UK-born & -0.178 & 0.126 & -0.030 & 0.046 & 0.037 \\
\hline & South-Asian migrant & -0.019 & -0.006 & $0.085^{\star * *}$ & $-0.076^{* *}$ & 0.016 \\
\hline & black Caribbean UK-born & 0.037 & -0.030 & -0.092 & -0.051 & $0.135^{\star \star *}$ \\
\hline & black African UK-born & 0.062 & 0.066 & $0.205^{\star * *}$ & 0.009 & $-0.342^{* * *}$ \\
\hline & black migrant & -0.057 & 0.016 & $0.140^{\star * *}$ & $-0.090^{\star *}$ & -0.009 \\
\hline \multirow{9}{*}{$\begin{array}{l}\text { Exposure to } \\
\text { co-ethnics } \\
\text { in } \\
\text { occupation } \\
\text { (log) }\end{array}$} & white UK-born & -0.061 & 0.009 & $-0.131^{* \star \star}$ & $0.134^{\star \star}$ & 0.049 \\
\hline & white migrant & 0.116 & 0.138 & $-0.169^{\star}$ & 0.013 & -0.097 \\
\hline & Indian UK-born & 0.019 & -0.023 & 0.017 & 0.013 & -0.027 \\
\hline & Pakistani UK-born & 0.015 & $-0.114^{\star * *}$ & 0.042 & 0.018 & 0.039 \\
\hline & Bangladeshi UK-born & -0.029 & 0.013 & 0.043 & 0.035 & -0.062 \\
\hline & South-Asian migrant & 0.024 & -0.008 & -0.011 & -0.004 & -0.000 \\
\hline & black Caribbean UK-born & 0.017 & $-0.050^{*}$ & 0.020 & -0.021 & 0.034 \\
\hline & black African UK-born & 0.127 & -0.023 & 0.046 & -0.038 & $-0.113^{*}$ \\
\hline & black migrant & 0.006 & 0.014 & 0.025 & $-0.079^{* *}$ & 0.034 \\
\hline
\end{tabular}

${ }^{* * *} p<0.01,{ }^{* *} p<0.05, * p<0.1$, showing estimated effect of 1-unit increase in a contextual factor on the average probability of class membership by ethnicity and migrant status, estimated from multinomial logistic regression models in which each contextual factor is interacted separately with ethnicity and migrant status, controlling for socio-demographic characteristics, local area characteristics, sector and occupational characteristics. 
Accepted version. Published as: Zwysen \& Demireva (2018). Ethnic and migrant penalties in job quality in the UK: the role of residential concentration and occupational clustering, Journal of Ethnic and Migration Studies.

Table 5: Estimated job class correcting for selection into work

\begin{tabular}{|c|c|c|c|c|c|}
\hline Men & High-quality & $\begin{array}{l}\text { High } \\
\text { intrinsic/low } \\
\text { rewards }\end{array}$ & Polarized & $\begin{array}{l}\text { Unhappy } \\
\text { 9to5 }\end{array}$ & Bad job \\
\hline white migrant & -0.004 & -0.008 & 0.013 & -0.014 & 0.013 \\
\hline Indian UK-born & $-0.042^{*}$ & $0.042 * *$ & $0.041^{*}$ & 0.028 & $-0.069 * * *$ \\
\hline Pakistani UK-born & $-0.067 *$ & $0.070 * *$ & 0.044 & $0.081 * * *$ & $-0.129 * * *$ \\
\hline Bangladeshi UK-born & -0.044 & 0.027 & $0.089 * *$ & $0.079 * * *$ & $-0.152 * * *$ \\
\hline south-Asian migrant & $-0.109 * * *$ & $0.027^{* *}$ & $0.031 *$ & 0.018 & $0.033^{* *}$ \\
\hline black Caribbean UK-born & -0.034 & -0.009 & $0.112 * * *$ & $0.047^{*}$ & $-0.116 * * *$ \\
\hline black African UK-born & -0.034 & -0.025 & -0.040 & $0.169 * * *$ & $-0.069 *$ \\
\hline black migrant & $-0.094 * * *$ & -0.025 & $0.090 * * *$ & $0.029 *$ & -0.001 \\
\hline $\mathrm{N}$ selected & 31,835 & 31,835 & 31,835 & 31,835 & 31,835 \\
\hline $\mathrm{N}$ non-selected & 12,900 & 12,900 & 12,900 & 12,900 & 12,900 \\
\hline \multicolumn{6}{|l|}{ Women } \\
\hline white migrant & $-0.020 * *$ & -0.009 & 0.001 & 0.011 & $0.017 * *$ \\
\hline Indian UK-born & 0.009 & 0.020 & -0.021 & 0.021 & $-0.029 *$ \\
\hline Pakistani UK-born & -0.010 & $0.061 * *$ & $-0.051 *$ & 0.023 & -0.022 \\
\hline Bangladeshi UK-born & 0.039 & $0.065^{* *}$ & 0.010 & -0.055 & $-0.060 *$ \\
\hline south-Asian migrant & $-0.081 * * *$ & $0.030 * *$ & 0.001 & -0.016 & $0.066 * * *$ \\
\hline black Caribbean UK-born & $0.044 * *$ & -0.023 & 0.007 & 0.003 & $-0.030 *$ \\
\hline black African UK-born & $0.074 * *$ & $-0.050 *$ & 0.033 & $-0.061^{*}$ & 0.004 \\
\hline black migrant & $-0.078 * * *$ & -0.010 & $0.112 * * *$ & -0.015 & -0.010 \\
\hline $\mathrm{N}$ selected & 41,311 & 41,311 & 41,311 & 41,311 & 41,311 \\
\hline $\mathrm{N}$ non-selected & 15,140 & 15,140 & 15,140 & 15,140 & 15,140 \\
\hline
\end{tabular}


Accepted version. Published as: Zwysen \& Demireva (2018). Ethnic and migrant penalties in job quality in the UK: the role of residential concentration and occupational clustering, Journal of Ethnic and Migration Studies.

\section{List of figures}

Figure 1: Job quality by NS-SEC

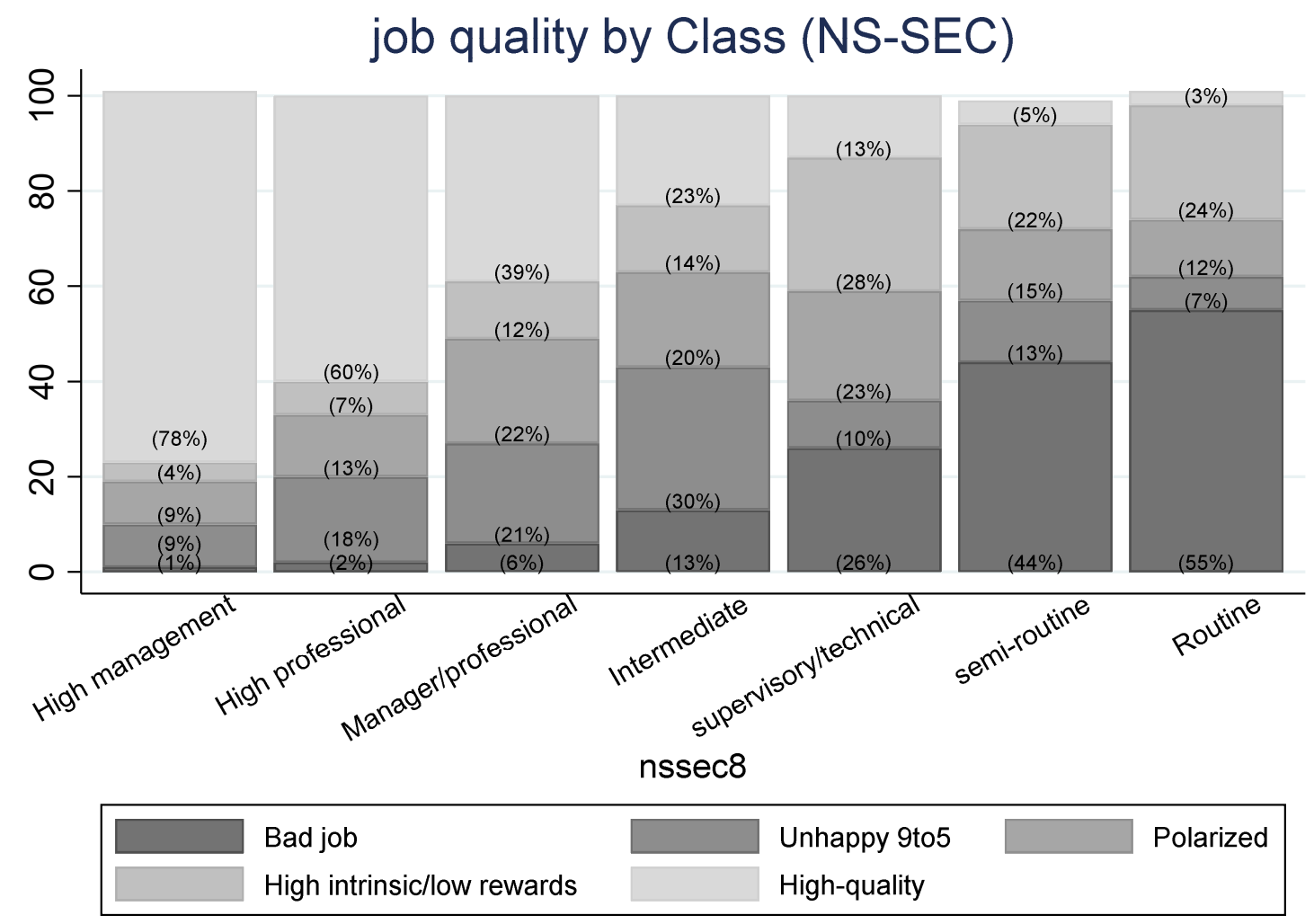

Source: UKHLS 2009-2017; shows class membership of estimated 5 latent classes by NS-SEC 
Accepted version. Published as: Zwysen \& Demireva (2018). Ethnic and migrant penalties in job quality in the UK: the role of residential concentration and occupational clustering, Journal of Ethnic and Migration Studies.

Figure 2: Job quality by ethnicity and country of birth

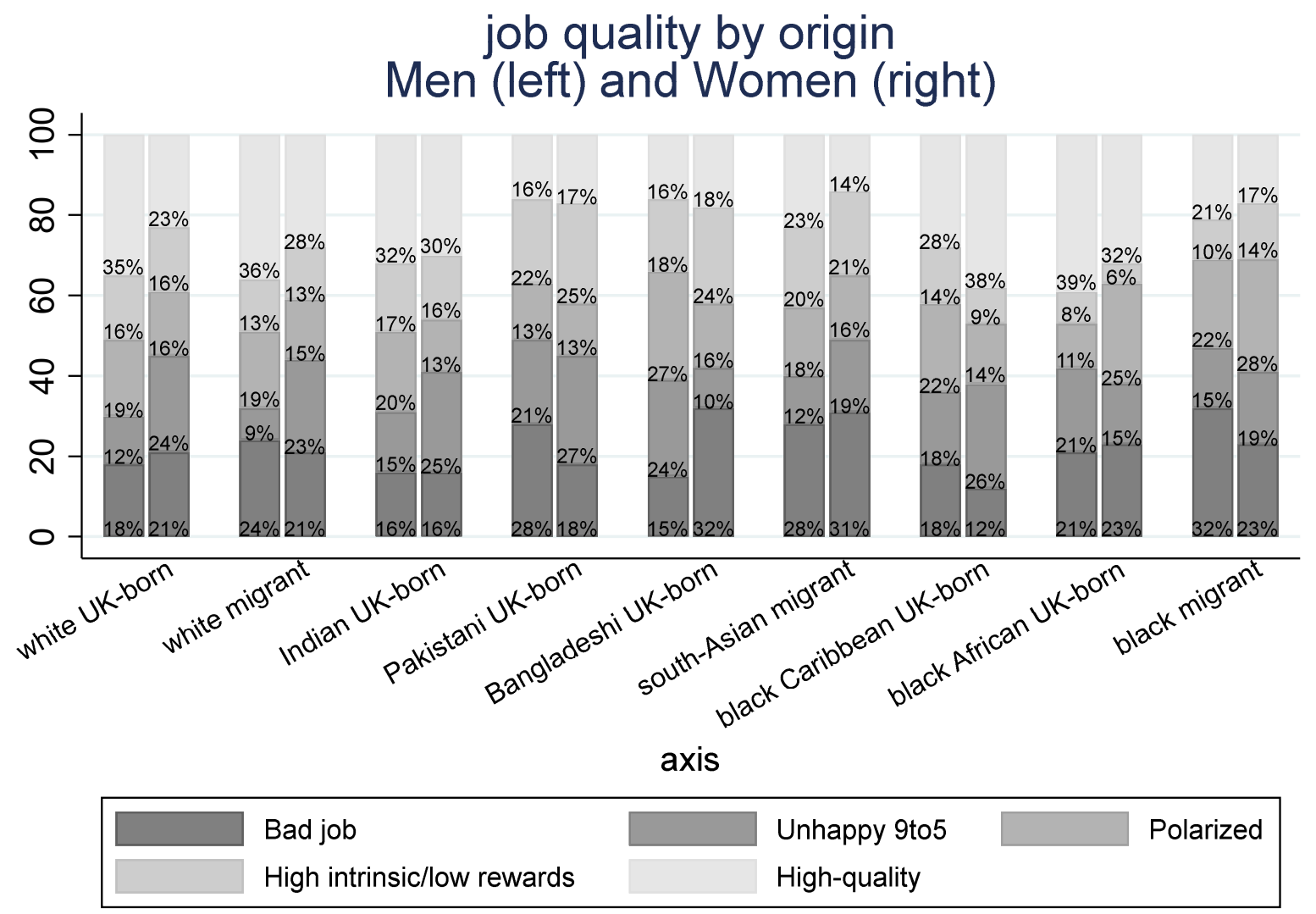

Source: UKHLS 2009-2017; shows class membership of estimated 5 latent classes by NS-SEC 
Accepted version. Published as: Zwysen \& Demireva (2018). Ethnic and migrant penalties in job quality in the UK: the role of residential concentration and occupational clustering, Journal of Ethnic and Migration Studies.

Figure 3: Ethnic penalties in job quality for men (95\% Confidence Interval)

\section{Ethnic/migrant penalty $[95 \% \mathrm{Cl}]$ on JQ: Men}
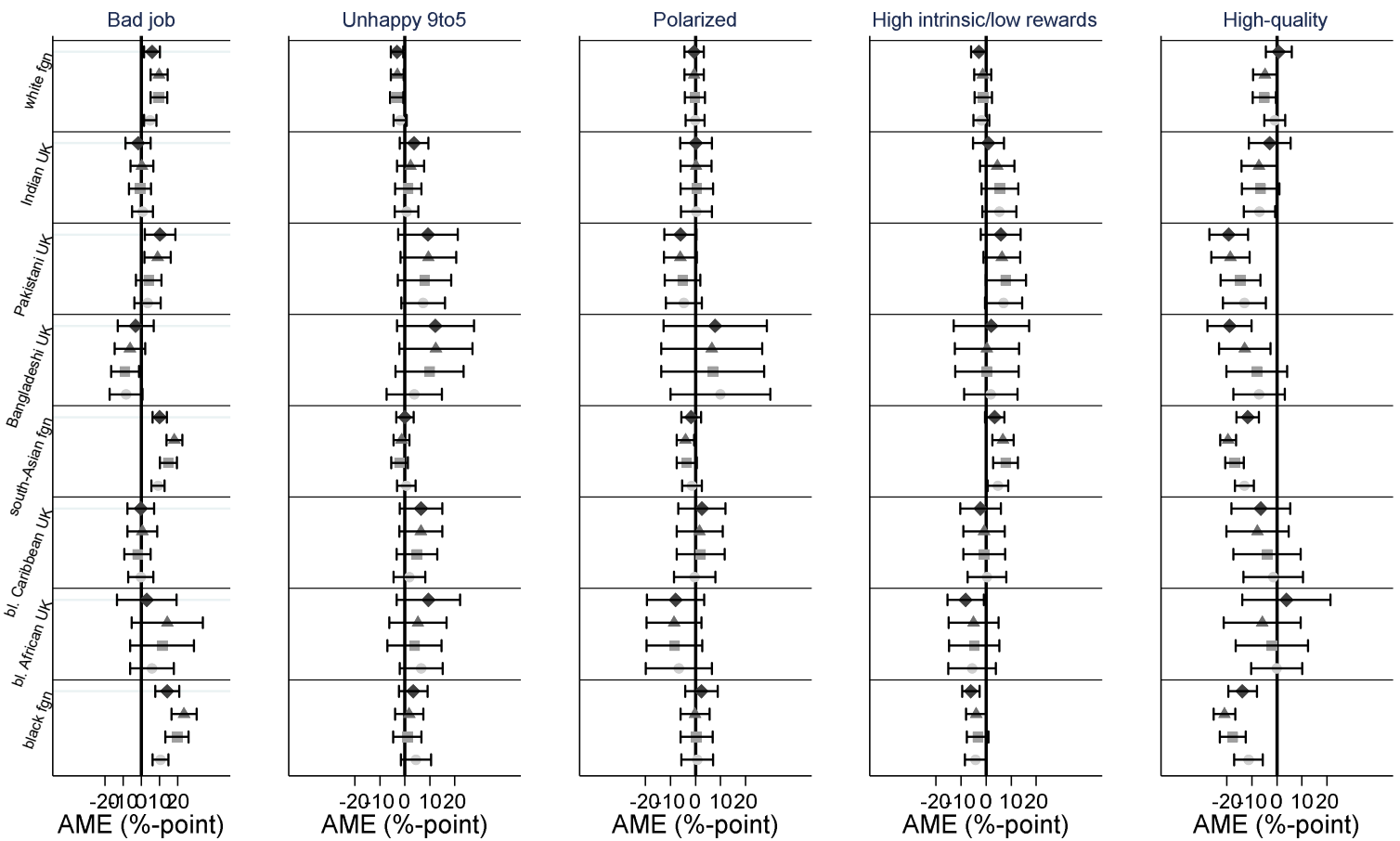

$\rightarrow$ Base $\triangle$ SD $\because$ Local $\circ$ Occ.

Source: UKHLS 2009-2017, showing predicted average marginal effects of class membership compared to UK-born whites with $95 \% \mathrm{Cl}$, estimated from weighted multinomial logistic regression with clustered standard errors by person.

Base includes origin (ethnicity and whether born in the UK); SD adds education, gender, age, age squared, urban, south-east, year (dummies), dependent child, marital; Local adds employment, share of graduates, share of managers/professionals and diversity at LSOA level; Occ adds sector, firm size, occupational (1-digit) controls and exposure to migrants. 
Accepted version. Published as: Zwysen \& Demireva (2018). Ethnic and migrant penalties in job quality in the UK: the role of residential concentration and occupational clustering, Journal of Ethnic and Migration Studies.

Figure 4: Origin penalties compared to UK-born whites: Men

\section{Ethnic/migrant penalty $[95 \% \mathrm{Cl}]$ on JQ: Women}
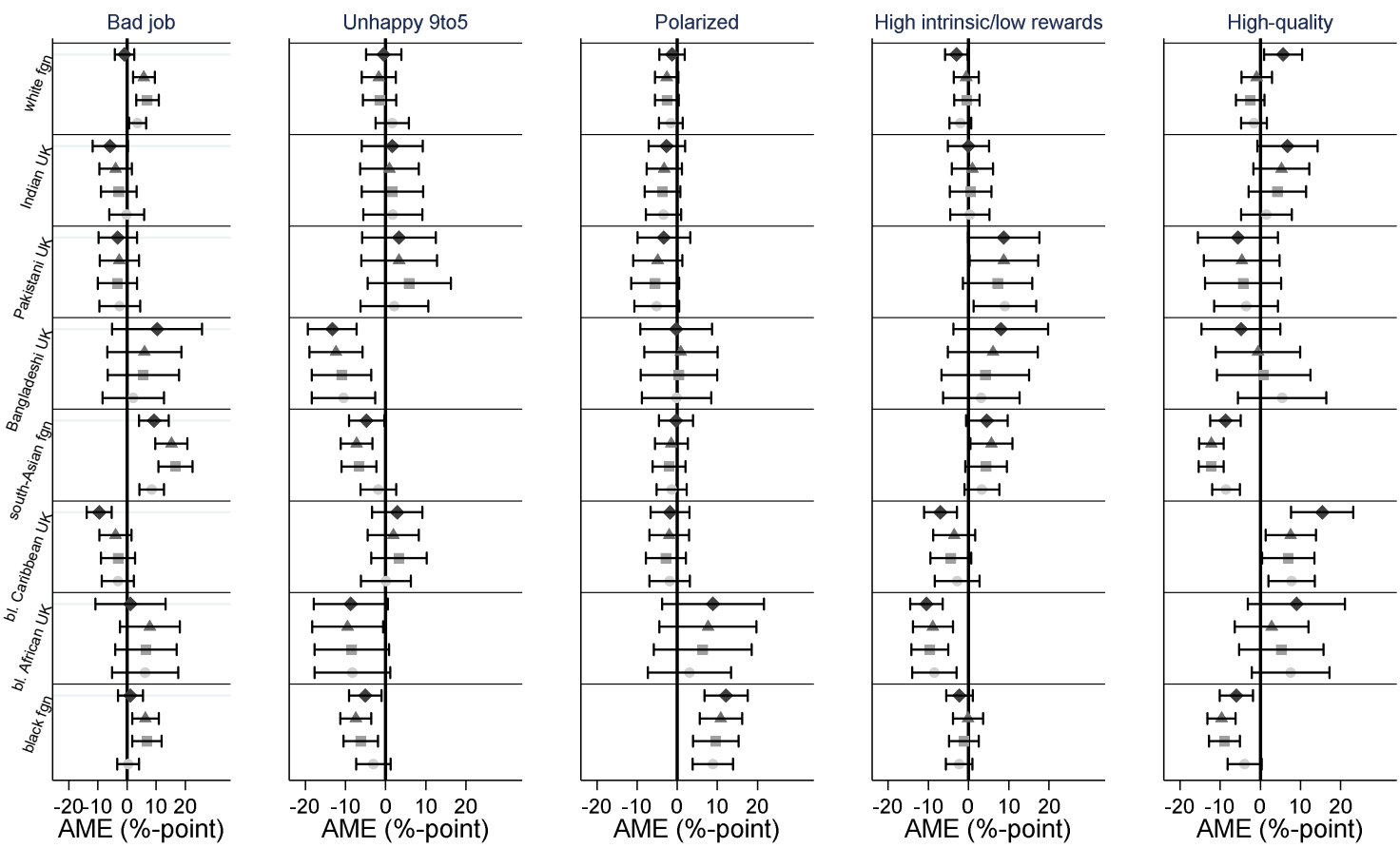

- Base $\triangle$ SD $\because$ Local Occ.

Source: UKHLS 2009-2017, showing predicted average marginal effects of class membership compared to UK-born whites with $95 \% \mathrm{Cl}$, estimated from weighted multinomial logistic regression with clustered standard errors by person.

Base includes origin (ethnicity and whether born in the UK); SD adds education, gender, age, age squared, urban, south-east, year (dummies), dependent child, marital; Local adds employment, share of graduates, share of managers/professionals and diversity at LSOA level; Occ adds sector, firm size, occupational (1-digit) controls and exposure to migrants. 